\title{
Effectiveness of Corporate Intranet in Selected Malaysian Companies
}

\author{
Mohamad Noorman Masrek \\ Faculty of Information Management, MARA University of Technology \\ Puncak Perdana Campus, Section U10, 40150 Shah Alam Selangor, Malaysia \\ Tel: 60-3-7962-2002Ｅ-mail: mnoorman@salam.uitm.edu.my
}

Kamaruzaman Jusoff (Corresponding author)

Faculty of Forestry, Universiti Putra Malaysia 43400 UPM Serdang Selangor, Malaysia

Tel: 60-3-8946-7176 E-mail: kamaruz@forr.upm.edu.my

Nor Shariza Abdul Karim

Faculty of Information and Communication Technology, International Islamic University

Jalan Gombak, 53100 Kuala Lumpur, Malaysia

Tel: 60-3-6196-5681Ｅ-mail: shariza@iiu.edu.my

\author{
Ramlah Hussein \\ Faculty of Information and Communication Technology, International Islamic University \\ Jalan Gombak 53100 Kuala Lumpur, Malaysia \\ Tel: 60-3-6196-5627 E-mail: ramlah@iiu.edu.my
}

The research is financed by Universiti Teknologi MARA

\begin{abstract}
This study was undertaken with the purpose of measuring intranet effectiveness in selected Malaysian companies. Defining effectiveness as composite constructs of intranet characteristics, intranet usage and individual performance, the study employed a cross-sectional survey method. A total of 359 users participated in the study. The intranet characteristics namely, task fit, information quality and systems quality are found to be significantly related to intranet usage. Likewise the three intranet variables, namely, usage mode, usage for decision support and usage for knowledge sharing are also found to be significantly related to individual performance measured in terms of task innovation, task productivity and personal sense of accomplishment. Hence, the study had indeed confirmed that intranets users in Malaysian companies have perceived their intranet to be effective
\end{abstract}

Keywords: Intranet, Corporate, Usage, Characteristics, Individual, Performance

\section{Introduction}

Since its first inception a decade ago, the intranet has achieved major advancement and sophistication. At present, intranet technologies have significantly mature and they exist in all sizes, shapes, and forms. In fact, more sophisticated terms like intranet portal, enterprise portal, enterprise information portal or EIP (Shilakes \& Tylman, 1998) have been coined to reflect the advancement and complexity of the technology. Concurrently, EIP vendors also started flourishing in the market. Nevertheless, as intranets are being equipped in most Malaysian corporate workplace environment, studies measuring their effectiveness from the user-level perspective are still very limited. Against this background, this study was undertaken with the purpose gauging intranet effectiveness. Adapting the work from Delone \& Mclean (1992, 2003), intranet effectiveness is defined as composite constructs of intranet characteristics, usage behavior and individual performance. Within the domain of IS, various theories and models have been developed to explain technology 
adoption and measuring its effectiveness. Accordingly, the model of this study is conceptualized based on the work of Trice \& Treacy (1988), Delone \& Mclean (1992), Goodhue \& Thompson (1995), Ali \& Money (2005) and Jeyaraj et al.(2006). Most of these models and frameworks were developed based Theory of Reasoned Actions or TRA (Fishbein \& Ajzen, 1975) and Theory of Planned Behavior or TPB (Ajzen, 1991). In essence, both TRA and TPB posited that individual behavior is determined by his or her belief and attitudes towards a particular object. Models such as Information Systems Success Model or ISSM (Delone \& Mclean, 1992) and Task Technology Fit or TTF (Goodhue \& Thompson, 1995) posited that technology usage is a predictor of individual impact or performance. Various studies adopting these two models have demonstrated that individual performances can be greatly enhanced through technology usage (e.g. D'Ambra \& Wilson, 2004; Iivari, 2005). Hence, the conceptualized framework, defined as the intranet effectiveness model from the user perspective was used in this study.

\section{Methods}

Several corporate enterprises were contacted to participate in the study. However, in order to be eligible, the intranet being used should be of high maturity i.e. being integrated with organizational information systems. Consequently, four corporate enterprises were found to fulfill the criteria and therefore chosen to participate. After lengthy discussion with representatives of these enterprises, it was decided that the respondents of the study should be the executives in the headquarters only. The rationale being that majority of the staffs ranging from the executives to top management were located here and furthermore, staffs working here directly involved in the core-business and core-functioning such as human resource, marketing, finance and service operation the organization. Hence, in the course of such activities the use of ICT such as intranet would be very rampant. A stratified random sampling technique was adopted so as to insure that respondents were well represented by various departments. Accordingly, 700 questionnaires were distributed to these participating companies, upon which 423 were returned but 359 were usable.

Other than demographic information, the questionnaire contained open-ended questions with seven point Likert scale. To measure task-fit, four-item scales adapted from Ali \& Money (2005) were used. To gauge information quality and systems quality, six-item scales and ten-item scales adapted from Ahn, Ryu \& Han (2004) and Roca et. al.(2006) were used. To measure decision support, four-item scales adapted from Doll \& Torkzadeh (1998) was developed. To measure knowledge sharing, an instrument comprising of six-item scales adapted from De Vries et. al. (2006) was developed. To measure individual performance which consists of task innovation, task productivity and personal sense of accomplishment, ten-item scales adapted from Torkzadeh \& Doll (1999) and Staples et. al. (2002) was used. Prior to actual data collection, the developed questionnaire was pilot tested involving 40 usable responses and reliability analysis conducted on the research instruments unveiled that it was soundly reliable.

\section{Results and discussion}

Based on 359 usable responses, data were analyzed using SPSS version 14.0. Non-response biases were checked by comparing early responders and late responders using independent sample t-test. Apparently the results showed that the responses were free from non-response biases. ANOVA test were also performed across companies to check whether significance differences could be observed on all the research variables. Evidently, no significant difference could be observed and following the results, responses from the four organizations were treated as one sample in subsequent analysis. Considering that this study was exploratory, factor analysis involving principal axis factoring with Varimax rotation was then executed on multi-items measures. In interpreting which factor loadings are worth considering, this study adopted loadings of 0.3, as suggested by Hair et al. (1998). All the measures were entered into principle axis factoring with Varimax rotation.

The exercise unveiled that despite few items that experienced cross-loadings, most items measuring intranet characteristics and individual performance variables were loaded into conceptualized variables. Due to the huge difference and the relatively higher factor loadings between factors, the cross-loaded items were retained on the factors representing the conceptualized variables. However, one item measuring knowledge sharing had to be eliminated as it had cross-loaded with other factor and the difference of the factor loading is very small. Hair et al. (1998) asserted that cross-loading reflects the high shared variance between variables and cautioned that when correlation among factors becomes higher; it becomes more cumbersome to differentiate which item load uniquely on the factor. In addition, two items measuring usage modes i.e. publishing and recording did not meet the cut off mark and thus removed from further analysis. Possible explanation for the low loadings of these two items could be attributed to the confounding effect of other two usage modes i.e. interacting and transacting. The practices of information publishing, especially memos are usually embedded together within interacting mode. In other words, users publish these types of information and consequently disseminate them via e-mail. Likewise, the practice of recording organizational knowledge could be perceived as similar to transacting mode. Recording of knowledge usually takes place via some form of computerized systems such as Knowledge Management Systems (KMS).Following the outcome of the factor analysis, reliability analyses were conducted on the variables employing multi-items measures. Accordingly, items measuring usage behavior had to be reduced into three as two items were found not to meet the cut-off value. Upon further investigation 
on reliability analysis discovered that Cronbach's alpha for information quality, systems quality, usage mode, decision support, knowledge sharing, and individual performance were $0.903,0.942,0.899,0.858,0.910$, and 0.952 respectively. Clearly, these values suggest that the instrument used in the study were highly reliable.

\subsection{Demographics}

Table 1 presents the demographic profiles of the research samples. Between male and female, the former seemed too outnumbered the later with $54.9 \%$ as opposed to $45.1 \%$. Age group between 31 and 35 was most dominant and contributed to $29.5 \%$ of the sample. In terms of qualifications, 284 respondents indicated to have gotten first degree while 23 indicated to have obtained Masters. 306 respondents indicated as holding executives posts while 53 were holding middle management post. The average length of service was 7.62 while intranet experience recorded a mean of 6.92 .

\section{$<<$ Table 1. Demographic Profiles $>>$}

\subsection{Relationship between variables}

In order to test the formulated hypotheses, correlation and regression analyses were performed. Correlation entails the provision of a yardstick whereby the intensity of strengths of a relationship can be measured (Bryman \& Cramer, 2001). However, correlation analysis gauges only the degree to which two variables are related or tend to move together but there is no assumption that one is causing or affecting the other (Alreck \& Settle, 1995). Hence, to measure the degree and direction of influence of the independent variable on the dependent variable, the regression analysis was also applied in this study. The result of exercise is shown at Table 2. Evidently, resulting from the correlation analysis, the values of the Pearson $r$ between all independent and dependent variables are well above 0.5 , suggesting moderate correlation but significant at 0.05 level. In addition, the results of the regression analysis between independent variables and dependent variables unveiled that the values of $\mathrm{R}^{2}$ are well above 0.30 indicating that the former are influential in explaining $30 \%$ or more variation in the latter. To this effect, it can be safely concluded that all of the formulated hypothesis are fully supported. Hence, the findings of this study further support previous studies by Phelps \& Mok (1999), Tang (2000), Young (2000), Miller (2004), Wilkie (2005), Deltour (2005) and Baptista et al. (2006). The findings also confirmed TRA, TPB, ISSM and TPCM in the context of intranet usage.

\section{$<<$ Table 2>> Results of the correlation and regression analysis}

\subsection{The Relationship between Intranet characteristics and intranet usage}

Theories such as TRA posited that object-based beliefs do have an effect on usage behavior. Model such as ISSM also posited similarly. In the context of this study, the three intranet characteristics namely, task-fit, information quality and systems quality were equivalent to object-based beliefs in TRA and ISSM. In congruent to these theories and models, all the three intranet characteristics were found to be strong determinants of intranet usage variables. In ensuring successful intranet usage among users, the intranet itself should inherit those characteristics that match users' job requirements. This situation which is also known as task fit is very critical as failing to accommodate users' need and requirements would further burden or cause more difficulties to users. Intranet functionalities' need and requirement varies across users. To respond to this diversity of needs and requirements, some intranet portals are equipped with the customization or personalization tool which enables users to personally customize their intranet functionalities according to their own preferences. The closer the intranet to fulfilling users' needs and expectations, the more they would be utilized by users. The crux of implementing information systems is to effectively manage information. In this information age, information is no longer treated as a byproducts of business transactions, rather, it is now considered as critical capital to organization well being. Even at the user level perspective, information usage especially among white collar jobs such as in this study, is so critical that without them almost no job can be carried out. Respondents of this study had evidently showed the importance of information quality in determining usage behavior. When the intranet matched users' information quality requirements, it would results in users utilizing the intranets.

In relation to information quality, systems quality also receives equal attention in terms of its importance from the users' perspective. The analogy between information quality and systems quality would be like the term 'effectiveness' and 'efficiency'. If the intranet could produce quality information as expected by users, then it deserves to be called effective. However, if the time taken to produce quality information is very slow because of its poor systems quality, then it is likely to be called inefficient. Apparently, both information quality and systems quality goes hand-in-hand. Therefore, addressing the systems quality of the intranet would guarantee usage among intranet users as evident by the findings of this study. The implication of the abovementioned finding is that it further strengthens TRA, TPB, ISSM and TPCM and suggests their applicability and relevancy in the context of intranet settings.

\subsection{The Relationship between Intranet Usage and Individual Performance}

Models such as ISSM and TPCM postulate that IS usage should lead to individual performance or effectiveness. Evidently, the findings fully support this and that intranet usage measured in terms of usage modes, usage for decision 
support and usage for knowledge sharing were found to be predictors of individual performance. As users engaged in the intranet in varying usage modes such as transacting, interacting and searching, various outcomes could be expected. As a result of transacting with various corporate information systems via the intranet, various corporate information could be retrieved in the form of report summaries, etc. This information would certainly be very useful input to the generation of new ideas or innovations. Transacting with automated information system would also lead to time saving, and hence resulting in better task productivity. Also, as work tasks are automated or computerized via the intranet, jobs become less laborious and would eventually lead towards better job satisfaction, higher work commitment and greater personal sense of accomplishment.

In terms of interacting modes, users could engage in diverse and intense communication among corporate members. By means of interacting, users could query or participate in various online discussions and consultations that would eventually develop new ideas and innovations. Similarly, by means of interacting, the information needs of users, either for job-related or personal usage, would be better served. Essentially, by means of interacting, users can always seek the help of others in the company. As such, help can be acquired either for job purposes or personal matter and would eventually translate towards better work productivity and enhanced personal sense of accomplishment. The searching mode of intranet usage enables users to access and retrieve diverse corporate information and knowledge. As a result of understanding corporate processes and procedures through the help of information and knowledge via means of searching from the internet, users could devise or develop new innovative ideas that are beneficial to the corporate well-being. Also, when corporate information searching and access becomes unproblematic but efficient and effective through the intranet, work tasks can be easily completed, hence boosting productivity. By means of the searching mode, the individuals could easily fulfill their diverse informational needs that would further relate to personal sense of accomplishment and self-satisfaction. In the course of completing work tasks, users would certainly deal with crucial decision making or problem solving. In certain circumstances, decision making or problem solving could not he handled by oneself and hence suggestions or inputs from others are seen critical. By means of utilizing the intranet, users could either search for critical information required for the decision making or problem solving, or alternatively they could seek the help from corporate members via means of the intranet. In the process, various ideas could be germinated and once the problems are solved and decisions have been made, new knowledge (i.e. the solution or decision) are created. In due course, users would definitely feel relieved and satisfied as their mission of problem solving have been accomplished.

Individuals vary in knowledge, skills and competencies. Via means of knowledge sharing among peers and colleagues or even among subordinates and superiors, one's skills and knowledge could be enriched and deepened. In an corporate context, the intranet has always been considered an effective tool in materializing knowledge sharing. By sharing knowledge with others, new knowledge would be created. Also, by sharing knowledge with those who are in dire need of that knowledge, this may even help them in improving work productivity, especially when the knowledge relates task or job performance. Similarly, when the required knowledge is obtained, for instance by means of the intranet, that individual would be surely pleased as his or her needs are accomplished. In sum, the findings have clearly shown that in an intranet computing environment, intranet usages do have significant relationship with individual performance.

\section{Conclusion}

Findings of the study have indeed ascertained that intranet users have perceived their intranet to effective evident from the supported hypotheses. Nonetheless, the major contribution of this study can be assessed from two perspectives i.e. theoretical and practical. Intranet, despite its widespread adoption among public and private organizations, has captured little interest of the IS researchers to investigate the nature of usage and the corresponding determinants and impacts especially at the user level. Consequently, the empirical based framework that depicts the determinants and impacts of intranet usage at the user-level perspective is unavailable until the establishment of the framework used in this study. The framework, which mainly derived from the fundamental Input-Process-Output model and other supporting theories such as TRA, TPB, ISSM and TPCM has been successfully validated in the context of this study. Indirectly, it also implies that the findings of this study have strengthened the theories, frameworks and models upon which the model has been built upon.

Future research should consider adopting every intranet user irrespective of their job level as respondents. As such, differences and comparisons can be made between job-level and status of intranet usage. Secondly, the perceptual measures adopted in the survey instrument are subject to individual interpretation and understanding. Hence, instead of using self-reported measures for gauging individual intranet usage, a more accurate approach would be to install software-tracking systems onto the intranet that would both monitor and record individual usage. However, such approached would be quite difficult unless permission and access are granted to the organization's intranet. It would be more interesting if the measures could capture the type of knowledge being shared via the usage of intranet.

\section{References}

Ahn, T., Ryu, S. \& Han, I. (2004). The impact of the online and offline features on the user acceptance of internet 
shopping malls. Electronic Commerce Research and Applications, 3, 405-420.

Ajzen, I. (1991). The theory of planned behavior. Organization Behavior and Human Decision Processes, 50(2), $179-211$.

Ali, A.S.B., \& Money, W.H. (2005). A study of project management systems acceptance. Proceedings of the $38^{\text {th }}$ Hawaii International Conference of Systems Science (HICSS2005), Hawaii, USA.

Alreck, P.L., \& Settle, R.B. (1995). The survey research handbook. Second Edition. Chicago: Irwin.

Bryman, A., \& Cramer, D. (2001). Quantitative data analysis with SPSS release 10 for Windows (also suitable for SPSS release 11): a guide for social scientist. New York: Routledge.

D'Ambra, J., \& Wilson, C. S. (2004). Explaining perceived performance of world wide web: uncertainty and the task technology-fit model. Internet Research, 14(4), 294-310.

De Vries, R. E., Den Hooff, B. V. \& De Ridder, J. A. (2006). Explaining knowledge sharing: the role of team communication styles, job satisfactions and communication beliefs. Communications Research, 33 (2), 115 - 135.

Delone, W.H. \& Mclean, E.R. (2002). The Delone and Mclean model of information systems success: a ten-year review. Journal of Management Information Systems, 19(4), 9-30.

Delone, W.H., \& Mclean, E.R. (1992). Information systems success: the quest for the dependent variable. Information Systems Research, 3(1), 60-95.

Deltour, F. (2005). Satisfaction, acceptance, impacts: linking three modalities to evaluate intranets at individual level. Proceedings of the $12^{\text {th }}$ European Conference on Information Technology Evaluation (ECITE2005), Turku, Finland.

Fishbein, N., \& Ajzen, I. (1975). Belief, attitude, intention and behavior: an introduction to theory and research. Reading, MA: Addison-Wesley.

Goodhue, D.L., \& Thompson, R.L. (1995). Task-technology fit and individual performance. MIS Quarterly, 19(2), 12 -236 .

Hair, J.F., Anderson, R.E., Tatham, R.L. \& Black, W.C. (1998). Multivariate data analysis. New Jersey: Prentice-Hall.

Iivari, J. (2005). An empirical test of the Delone-Mclean model of information systems success. The DATABASE for Advances in Information Systems, 36(2), 8-27.

Jeyaraj, A., Rottman, J.W. \& Lacity, M.C. (2006). A review of predictors, linkages and biases in IT innovation adoption research, Journal of Information Technology, 21, 1-23.

Miller, R. (2004). Measuring intranet effectiveness. Prescient Digital Media. Retrieved August 18, 2005 From http://www.prescientdigital.com/Prescient_Research/Articles/Intranet_Articles/Measuring_Intranet_Effectiveness.htm

Phelps, R., \& Mok, M. (1999). Managing the risks of intranet implementation: an empirical study of user satisfaction. Journal of Information Technology, 14, 39-52.

Roca, J.C., Chiu, C.M. \& Martinez, F.J. (2006). Understanding e-learning continuance intention: an extension of the Technology Acceptance Model. International Journal of Human Computer Studies, 64(8), 683-696.

Shilakes, C., \& Tylman, J. (1998). Enterprise information portals. New York: Merrill Lynch, Inc.

Staples, D.S., Wong, I., \& Seddon, P.B. (2002). Having expectations of information systems benefits that matched received benefits: does it really matter? Information and Management, 40(2), 115-131.

Tang, S.M. (2000). An impact factor model of intranet adoption: an exploratory and empirical research. The Journal of Systems and Software, 51, 157-173.

Torkzadeh, G., \& Doll, W.J. (1999). The development of a tool for measuring the perceived impact of information technology on work. Omega, 27 (7), 327-339.

Trice, A.W. \& Treacy, M.E. (1988). Usage as dependent variable in MIS research. Database, 33-41.

Wilkie, K.J. (2005). An investigation on how intranets supports user task. Unpublished masters dissertation. The University of North Carolina at Chapel Hill, USA.

Young, L.Y. (2000). Factors affecting user satisfaction on Intranet. Unpublished Master's thesis, National Sun Yat-Sen University, Taiwan. 
Table 1. Demographic Profiles

\begin{tabular}{|l|l|l|l|}
\hline & Gender & Freq & $\%$ \\
\hline \multirow{4}{*}{ Gender } & Male & 197 & 54.9 \\
\cline { 2 - 4 } & Female & 162 & 45.1 \\
\hline \multirow{5}{*}{ Qualifications } & $20-25$ & 33 & 9.2 \\
\cline { 2 - 4 } & $26-30$ & 91 & 25.3 \\
\cline { 2 - 4 } & $31-35$ & 106 & 29.5 \\
\cline { 2 - 4 } & $36-40$ & 85 & 23.7 \\
\cline { 2 - 4 } & $41-45$ & 33 & 9.2 \\
\cline { 2 - 4 } & $46-50$ & 6 & 1.7 \\
\cline { 2 - 4 } & Master & 5 & 1.4 \\
\cline { 2 - 4 } & Degree & 23 & 6.4 \\
\cline { 2 - 4 } & Diploma & 28 & 79.1 \\
\hline \multirow{5}{*}{ Job Level } & Executive & 24 & 7.8 \\
\cline { 2 - 4 } & Mid. Mgt. & 306 & 85.2 \\
\hline
\end{tabular}

Table 2. Results of the correlation and regression analysis

\begin{tabular}{|c|c|c|c|c|c|c|c|c|}
\hline $\begin{array}{l}\text { Independent } \\
\text { variable }\end{array}$ & $\begin{array}{l}\text { Dependent } \\
\text { variable }\end{array}$ & $\mathrm{r} / \beta$ & $\begin{array}{l}\mathrm{R} \\
\text { Square }\end{array}$ & $\begin{array}{l}\text { Adjusted } \\
\mathrm{R}^{2}\end{array}$ & $\mathrm{~F}(1,357)$ & $\mathrm{t}$ & $\begin{array}{l}\mathrm{p} \\
\text { value }\end{array}$ & $\begin{array}{l}\text { Hypothesis } \\
\text { Results }\end{array}$ \\
\hline $\begin{array}{l}\text { Task } \\
\text { fit }\end{array}$ & Usage mode & $0.575^{*}$ & 0.331 & 0.329 & 176.537 & 13.287 & 0.000 & $\begin{array}{l}\text { H1a: } \\
\text { Supported }\end{array}$ \\
\hline $\begin{array}{l}\text { Information } \\
\text { quality }\end{array}$ & Usage mode & $0.567 *$ & 0.321 & 0.319 & 168.762 & 12.991 & 0.000 & $\begin{array}{l}\mathrm{H} 2 \mathrm{a}: \\
\text { Supported }\end{array}$ \\
\hline $\begin{array}{l}\text { System } \\
\text { quality }\end{array}$ & Usage mode & $0.579 *$ & 0.336 & 0.334 & 180.374 & 13.420 & 0.000 & $\begin{array}{l}\text { H3a: } \\
\text { Supported }\end{array}$ \\
\hline $\begin{array}{l}\text { Task } \\
\text { fit }\end{array}$ & $\begin{array}{l}\text { Decision } \\
\text { support }\end{array}$ & $0.571 *$ & 0.326 & 0.324 & 172.310 & 13.127 & 0.000 & $\begin{array}{l}\text { H1b: } \\
\text { Supported }\end{array}$ \\
\hline $\begin{array}{l}\text { Information } \\
\text { quality }\end{array}$ & $\begin{array}{l}\text { Decision } \\
\text { support }\end{array}$ & $0.576^{*}$ & 0.332 & 0.330 & 177.159 & 13.310 & 0.000 & $\begin{array}{l}\mathrm{H} 2 \mathrm{~b}: \\
\text { Supported }\end{array}$ \\
\hline $\begin{array}{l}\text { System } \\
\text { quality }\end{array}$ & $\begin{array}{l}\text { Decision } \\
\text { support }\end{array}$ & $0.536^{*}$ & 0.288 & 0.286 & 144.268 & 12.101 & 0.000 & $\begin{array}{l}\mathrm{H} 3 \mathrm{~b}: \\
\text { Supported }\end{array}$ \\
\hline $\begin{array}{l}\text { Task } \\
\text { fit }\end{array}$ & $\begin{array}{l}\text { Knowledge } \\
\text { sharing }\end{array}$ & $0.599 *$ & 0.358 & 0.357 & 199.398 & 14.211 & 0.000 & $\begin{array}{l}\text { H1c: } \\
\text { Supported }\end{array}$ \\
\hline $\begin{array}{l}\text { Information } \\
\text { quality }\end{array}$ & $\begin{array}{l}\text { Knowledge } \\
\text { sharing }\end{array}$ & $0.620 *$ & 0.385 & 0.383 & 223.408 & 14.947 & 0.000 & $\begin{array}{l}\mathrm{H} 2 \mathrm{c}: \\
\text { Supported }\end{array}$ \\
\hline $\begin{array}{l}\text { System } \\
\text { quality }\end{array}$ & $\begin{array}{l}\text { Knowledge } \\
\text { sharing }\end{array}$ & $0.569 *$ & 0.324 & 0.322 & 171.151 & 13.082 & 0.000 & $\begin{array}{l}\text { H3c: } \\
\text { Supported }\end{array}$ \\
\hline Usage mode & $\begin{array}{l}\text { Individual } \\
\text { performance }\end{array}$ & $0.638 *$ & 0.407 & 0.405 & 244.709 & 15.643 & 0.000 & $\begin{array}{l}\mathrm{H} 4: \\
\text { Supported }\end{array}$ \\
\hline $\begin{array}{l}\text { Decision } \\
\text { support }\end{array}$ & $\begin{array}{l}\text { Individual } \\
\text { performance }\end{array}$ & $0.571 *$ & 0.326 & 0.324 & 172.341 & 13.128 & 0.000 & $\begin{array}{l}\text { H5: } \\
\text { Supported }\end{array}$ \\
\hline $\begin{array}{l}\text { Knowledge } \\
\text { sharing }\end{array}$ & $\begin{array}{l}\text { Individual } \\
\text { performance }\end{array}$ & $0.635^{*}$ & 0.403 & 0.402 & 241.482 & 15.540 & 0.000 & $\begin{array}{l}\text { H6: } \\
\text { Supported }\end{array}$ \\
\hline
\end{tabular}

* Correlation is significant at 0.01 level (2-tailed) 